\title{
SYNTHESIS, CHARACTERIZATION AND CRYSTAL STRUCTURE OF A NOVEL DECAVANADATE SALT, $\left[\mathrm{V}_{0.50}\left(\mathrm{H}_{2} \mathrm{O}\right)_{5}\right]_{2}\left[\mathrm{H}_{2}\left(\mathrm{~V}_{10} \mathrm{O}_{28}\right)\right] \cdot 4\left(\mathrm{H}_{2} \mathrm{O}\right)$
}

\author{
ENDER BIÇER ${ }^{1, *}, N E C M I ̇ D E G E^{2}$, EMINE COŞKUN
}

\author{
${ }^{1}$ Department of Chemistry, Faculty of Arts and Sciences, Ondokuz Mayls University, 55139 Atakum-Samsun, Turkey \\ ${ }^{2}$ Department of Physics, Faculty of Arts and Sciences, Ondokuz Mayls University, 55139 Atakum-Samsun, Turkey
}

\begin{abstract}
A novel decavanadate salt, $\left[\mathrm{V}_{0.50}\left(\mathrm{H}_{2} \mathrm{O}\right)_{5}\right]_{2}\left[\mathrm{H}_{2}\left(\mathrm{~V}_{10} \mathrm{O}_{28}\right)\right] \cdot 4\left(\mathrm{H}_{2} \mathrm{O}\right)$, was obtained by the reaction of $\mathrm{NH}_{4} \mathrm{VO}_{3}$ with chinhydrone in an acidic medium. The title compound was characterized in the solid and solution phases by FT-IR, single crystal X-ray diffraction, voltammetry, UV-Vis., EPR and NMR measurements. The crystal data of the compound are: $\mathrm{H}_{30} \mathrm{O}_{42} \mathrm{~V}_{11}$, triclinic, $P \overline{\mathrm{1}}, a=8.4906$ (4) $\AA, b=10.4236(5) \AA, c=11.2861(6) \AA, \alpha=68.490(4)^{\circ}, \beta=87.251(4)^{\circ}, \gamma=67.145$ $(4)^{\circ}, V=851.11(8) \AA^{3}$, and $Z=1$. In the structure, $\left[\mathrm{H}_{2}\left(\mathrm{~V}_{10} \mathrm{O}_{28}\right]^{4-}\right.$ anion is bound via hydrogen bonds to the dimer state of $\left[\mathrm{V}_{0.50}\left(\mathrm{H}_{2} \mathrm{O}\right)_{5}\right]^{2+}$ cations and the water molecules. At this dimer moiety, it has been thought that the oxygen atoms of two water molecules form the bridges between two V(IV) center ions. The presence of high spin V(IV) $(I=7 / 2)$ in the compound was verified by EPR measurements. In addition, decavanadate unit gave a shoulder at about $400 \mathrm{~nm}$ on the UV-Vis. spectrum of the compound. Moreover, at the FT-IR spectrum, the symmetric and asymmetric stretching vibrations of the bridging V-O-V units were observed. On the cyclic voltammogram of the compound, two reduction peaks (V(V)-V(IV) and $\mathrm{V}(\mathrm{IV})-\mathrm{V}$ (II) reduction steps, respectively) at -1.03 and $-1.35 \mathrm{~V}$ were observed at the cathodic scan; however, one oxidation peak (V(II)-V(III) oxidation step) at $-1.22 \mathrm{~V}$ showed at the anodic scan. NMR results also support that the synthesized salt includes the coordinated water molecules and hydroxo groups.
\end{abstract}

Keywords: Decavanadate, V(V) and V(IV) units, chinhydrone, single crystal, water-bridged dimer

\section{INTRODUCTION}

As a trace transition metal, vanadium has some biological, pharmacological and physicochemical properties. ${ }^{1-7}$ In recent years, the interest to the chemistry of oxovanadates has grown considerably. ${ }^{8}$ The increasing interest is mainly owing to the role of vanadium in several biological processes such as the regulation of glucose level in the blood of diabetic animals and patients. $3,4,9-17$ Moreover, decavanadate and oxovanadates have many biological activities and been successfully used for the comprehension of several biochemical processes. ${ }^{18}$ Other interest for vanadium oxides is sourced from their potential uses as secondary cathode materials, both catalysis and electronics. ${ }^{19-21}$

Decavanadates, $\quad\left[\mathrm{H}_{\mathrm{n}} \mathrm{V}_{10} \mathrm{O}_{28}\right]^{(6-\mathrm{n})-}$, are known as predominant polyoxovanadate species in the acidic $\mathrm{pH}$ range and also consist of three chemically different vanadium sites; the metal sites at the central junction correspond to two central $\mathrm{VO}_{6}$ octahedra containing only bridging oxygen atoms, and two types of peripheral vanadium unit including a $\mathrm{V}=\mathrm{O}$ bond are assembled around the central units. ${ }^{22}$ In aqueous medium, under some conditions, the vanadate oligomers may be in equilibrium with monomeric $\left(\mathrm{V}_{1}\right)$, dimeric $\left(\mathrm{V}_{2}\right)$ and tetrameric $\left(\mathrm{V}_{4}\right)$ vanadate species. ${ }^{23}$

In the literature, the crystal structures of the decavanadate anion, $\left[\mathrm{V}_{10} \mathrm{O}_{27}\right]^{6-24}$ and its many salts (e.g. $\left(\mathrm{NH}_{4}\right)_{2}\left[\mathrm{Sr}\left(\mathrm{H}_{2} \mathrm{O}\right)_{8}\right]_{2}\left[\mathrm{~V}_{10} \mathrm{O}_{28}\right] \cdot 2 \mathrm{H}_{2} \mathrm{O}{ }^{25}$ $\mathrm{K}_{2}\left[\mathrm{Zn}\left(\mathrm{H}_{2} \mathrm{O}\right)_{6}\right]_{2}\left[\mathrm{~V}_{10} \mathrm{O}_{28}\right] \cdot 4 \mathrm{H}_{2} \mathrm{O},{ }^{24} \mathrm{~K}_{2}\left[\mathrm{Co}\left(\mathrm{H}_{2} \mathrm{O}\right)_{6}\right]_{2}\left[\mathrm{~V}_{10} \mathrm{O}_{28}\right] \cdot 4 \mathrm{H}_{2} \mathrm{O},{ }^{26}\left[\mathrm{Na}\left(\mathrm{H}_{2} \mathrm{O}\right)_{3}\right]_{2}[\mathrm{~N}$ $\left.\left.\mathrm{i}\left(\mathrm{H}_{2} \mathrm{O}\right)_{6}\right]_{2}\left[\mathrm{~V}_{10} \mathrm{O}_{28}\right] \cdot 4 \mathrm{H}_{2} \mathrm{O} \cdot \cdot^{27}\right)$, containing the different transition metal complex cations were characterized. The aim of this research was the synthesis, physicochemical characterization both in the aqueous solution and in the solid state, and the determination of molecular structure of a novel vanadium complex in the presence of chinhydrone.

\section{EXPERIMENTAL}

Chemicals and Solutions

$\mathrm{NH}_{4} \mathrm{VO}_{3}$ and chinhydrone were purchased from Merck and used as supplied. All the chemicals were of analytical-reagent grade. The solutions were prepared with ultra-pure water (specific resistivity: $18.2 \mathrm{M} \Omega \mathrm{cm}$ ). 0.1 $\mathrm{M} \mathrm{KBr}$ solution was used as the supporting electrolyte for the voltammetric measurements.

\section{Synthesis}

$\mathrm{NH}_{4} \mathrm{VO}_{3}(0.01 \mathrm{~mol})$ and chinhydrone $(0.03 \mathrm{~mol})$ were mixed in $100 \mathrm{~mL}$ of ethanol-water mixture $(40: 60, \mathrm{v} / \mathrm{v})$ and refluxed at $60^{\circ} \mathrm{C}$ with stirring for 2-hours. Then, the acidity was adjusted to $\mathrm{pH} 5-6$ with glacial acetic acid. The generated solution was filtered and cooled to room temperature. After 1 day, the complex formation was observed. But, surprisingly, instead of vanadiumchinhydrone complex, a decavanadate salt which does not contain chinhydrone has been obtained. The similar case was observed for glutamic acid or glutamine in a previous study. ${ }^{28}$

\section{Voltammetric Measurements}

The voltammograms were recorded at room temperature using an EG\&G PAR Model 384B polarographic analyzer controlled by a personal computer containing the ECDSOFT ${ }^{29}$ software in conjunction with an EG\&G PARC Model 303A SMDE stand, including a $\mathrm{Hg}$ working electrode, a Pt auxiliary electrode and an $\mathrm{Ag}|\mathrm{AgCl}| \mathrm{KCl}_{\text {sat. }}$ reference electrode.

\section{Spectroscopic Measurements}

The FT-IR spectrum was recorded with a Perkin Elmer Spectrum Two FTIR spectrometer $\left(4000-450 \mathrm{~cm}^{-1}\right)$ using $\mathrm{KBr}$ pellet. The electronic spectrum was carried out by using a Thermo Scientific Evolution Array EA-1301005 UV-Vis. spectrophotometer in the range of 200-800 nm with quartz cell of $1 \mathrm{~cm}$ length. The X-band EPR spectrum of compound was recorded on a Bruker EMX X-band spectrometer using $100 \mathrm{kHz}$ magnetic field modulation, $9.751 \mathrm{GHz}$ microwave frequency, $1 \mathrm{mT}$ modulation amplitude and $20.02 \mathrm{~mW}$ microwave power. The ${ }^{1} \mathrm{H}$ NMR spectrum was recorded on a Mercury-300BB $\left(300 \mathrm{MHz}\right.$ ) spectrometer, using $\mathrm{D}_{2} \mathrm{O}$ as a solvent and tetramethylsilane (TMS, $\delta 0 \mathrm{ppm})$ as an internal standard. The above spectroscopic measurements were carried out at ambient temperature.

\section{X-ray Crystal Structure Determination}

A suitable single crystal with dimensions $0.27 \times 0.23 \times 0.19 \mathrm{~mm}$ was chosen for the crystallographic study and then carefully mounted on goniometer of a STOE IPDS II diffractometer. Data collection of the title compound, $\mathrm{H}_{30} \mathrm{O}_{42} \mathrm{~V}_{11}$ was performed with STOE IPDS II single crystal X-ray diffractometer using graphite monochromated Mo K $\alpha$ radiation $(\lambda=0.71073 \AA)$ at room temperature ( $296 \mathrm{~K})$. Details of the data collection conditions and parameters of refinement process are given in Table 1. Cell parameters were obtained by using X-AREA ${ }^{30}$ and data reduction was achieved with X-RED $32^{30}$ software. The maximum peaks and deepest hole observed in the final $\Delta \rho$ map were 0.54 and $-0.76 \mathrm{e}$ $\AA^{-3}$, respectively. The scattering factors were taken from SHELXL-97..$^{31}$ The molecular graphics were drawn using ORTEP-3 for Windows. ${ }^{32}$ All nonhydrogen atoms were refined anisotropically. The coordinates of the $\mathrm{H}$ atoms of the water molecules were determined from a difference Fourier map and refined isotropically subject to a restraint of $\mathrm{O}-\mathrm{H}=0.82(4) \AA$. The generalpurpose crystallographic tool PLATON ${ }^{33}$ was used for the structure analysis. WinGX ${ }^{34}$ was used to prepare the data for publication. 
Table 1. Crystallographic data and refinement parameters for the compound.

\begin{tabular}{|l|l|}
\hline Crystal data & \\
\hline $\begin{array}{l}\text { Chemical sum formula } \\
\text { Moiety formula }\end{array}$ & $\begin{array}{l}\mathrm{H}_{30} \mathrm{O}_{42} \mathrm{~V}_{11} \\
{\left[\mathrm{~V}_{0.50}\left(\mathrm{H}_{2} \mathrm{O}\right)_{5}\right]_{2}\left[\mathrm{H}_{2}\left(\mathrm{~V}_{10} \mathrm{O}_{28}\right) \cdot 4\left(\mathrm{H}_{2} \mathrm{O}\right)\right.}\end{array}$ \\
\hline$M_{\mathrm{r}}$ & 1262.58 \\
\hline Crystal system, space group & Triclinic, $\mathrm{P} \overline{1}$ \\
\hline Temperature $(\mathrm{K})$ & 296 \\
\hline$a, b, c(\AA)$ & $8.4906(4), 10.4236(5), 11.2861(6)$ \\
\hline$\alpha, \beta, \gamma\left({ }^{\circ}\right)$ & $68.490(4), 87.251(4), 67.145(4)$ \\
\hline$V\left(\AA^{3}\right)$ & $851.11(8)$ \\
\hline$Z$ & 1 \\
\hline Radiation type & Mo K $\alpha$ \\
\hline$\mu($ mm
\end{tabular}

\section{RESULTS AND DISCUSSION}

FT-IR Spectroscopy Measurements

For the characterization of this new vanadium salt, its infrared spectrum has also been taken (Fig. 1). Based on IR spectrum in Fig. 1 and the literature information, ${ }^{28,35-37}$ the proposed assignments for some important bands are presented in Table 2 .

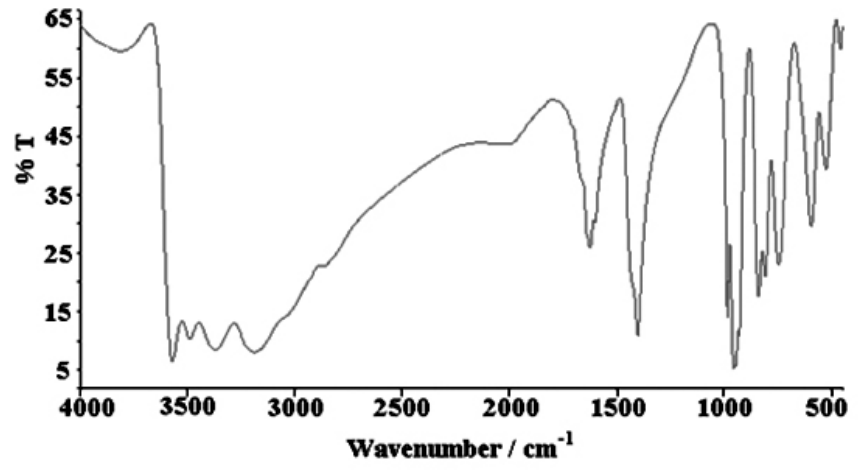

Figure 1. FT-IR spectrum of $\left[\mathrm{V}_{0.50}\left(\mathrm{H}_{2} \mathrm{O}\right)_{5}\right]_{2}\left[\mathrm{H}_{2}\left(\mathrm{~V}_{10} \mathrm{O}_{28}\right)\right] \cdot 4\left(\mathrm{H}_{2} \mathrm{O}\right)$
Table 2. Assignments of the some important IR bands $\left(\mathrm{cm}^{-1}\right)$ of $\left[\mathrm{V}_{0.50}\left(\mathrm{H}_{2} \mathrm{O}\right.\right.$ )$\left._{5}\right]_{2}\left[\mathrm{H}_{2}\left(\mathrm{~V}_{10} \mathrm{O}_{28}\right)\right] \cdot 4\left(\mathrm{H}_{2} \mathrm{O}\right)$

\begin{tabular}{|c|c|}
\hline Infrared bands $\left(\mathrm{cm}^{-1}\right)$ & Assignment \\
\hline 525.81 & $v_{\mathrm{s}}(\mathrm{V}-\mathrm{O}-\mathrm{V})$ \\
\hline 593.93 & \\
\hline 745.31 & $v_{\text {as }}(\mathrm{V}-\mathrm{O}-\mathrm{V})$ \\
\hline 808.46 & \\
840.18 & $v(\mathrm{~V}=\mathrm{O})$ \\
\hline 984.19 & \\
\hline 955.27 & $v(\mathrm{O}-\mathrm{H})$ \\
\hline 1626.81 & \\
\hline
\end{tabular}

It is well known that the symmetric and asymmetric stretching modes of the bridging $\mathrm{V}-\mathrm{O}-\mathrm{V}$ groups are between $\sim 450$ and $\sim 850 \mathrm{~cm}^{-1} .{ }^{38}$ As can be seen in Fig. 1, the bands at $3188.64,3368.48,3488.80$ and $3570.96 \mathrm{~cm}^{-1}$ and the sharp band at $1626.81 \mathrm{~cm}^{-1}$ are indicative of the presence of water molecules in the vanadium coordination sphere. ${ }^{39-41}$ It has been seen that the water stretching bands $\left(3188.64,3368.48,3488.80\right.$ and $\left.3570.96 \mathrm{~cm}^{-1}\right)$ are very complex when compared with the water bending mode at $1626.81 \mathrm{~cm}^{-1}$. Nevertheless, the bands at 3188.64 and $3368.48 \mathrm{~cm}^{-1}$ can be resulted from the $\mathrm{OH}$ stretching vibration of strongly hydrogen bonded water rather than $\mathrm{OH}$ units. ${ }^{42}$ Other two bands 3488.80 and $3570.96 \mathrm{~cm}^{-1}$ may be attributed to $\mathrm{OH}$ modes of hydroxyl units. ${ }^{42}$ Finally, the observed band at $1402.20 \mathrm{~cm}^{-1}$ can be identified as due to $\mathrm{O}-\mathrm{H}$ bending $(\delta \mathrm{OH}$ in-plane $){ }^{43}$

UV-Vis. Spectroscopy Measurements

The electronic spectrum of this compound was recorded in $\mathrm{KBr}$ solution in the range of 200-800 $\mathrm{nm}$ (Fig. 2). Fig. 2 shows a relatively sharp band at $246.7 \mathrm{~nm}$ and one shoulder with very low intensity at about $400 \mathrm{~nm}$, attributed to the charge transfer and $d \rightarrow d^{2}$ transitions, ${ }^{44-47}$ respectively. However, it was reported that the binuclear V(III) complex with hydroxyl bridges exhibited a charged transfer band in $436 \mathrm{~nm}$, having high absorptivity values. ${ }^{48}$ Hence, the electronic spectrum of the synthesized compound is different from that of V(III)-hydroxo complexes. ${ }^{48}$ Finally, it can be said that the structure of the compound does not include a binuclear V(III) complex-ion of di-ol type $\left[\left(\mathrm{H}_{2} \mathrm{O}\right)_{4} \mathrm{~V}(\mathrm{OH})_{2} \mathrm{~V}\left(\mathrm{H}_{2} \mathrm{O}\right)_{4}\right]^{4+}$. On the other hand, decavanadate, the decamer of monovanadate, can be distinguished by its absorbance at $400 \mathrm{~nm}^{49}$ Because this absorption band is characteristic of decameric vanadate. ${ }^{50}$ Therefore, the shoulder at $400 \mathrm{~nm}$ may also contain the absorption additives from decavanadate moiety of the compound.

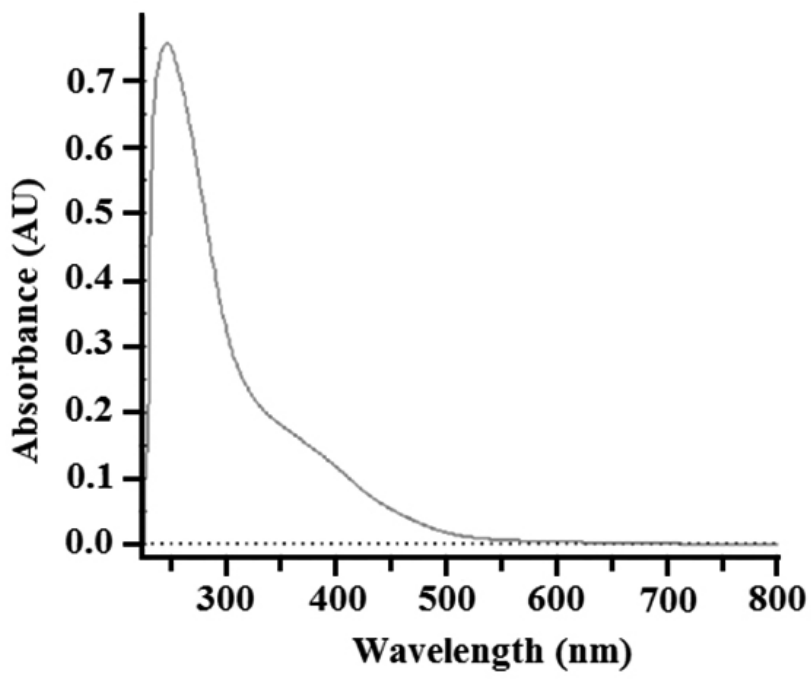

Figure 2. Electronic spectrum of $\left[\mathrm{V}_{0.50}\left(\mathrm{H}_{2} \mathrm{O}\right)_{5}\right]_{2}\left[\mathrm{H}_{2}\left(\mathrm{~V}_{10} \mathrm{O}_{28}\right)\right] \cdot 4\left(\mathrm{H}_{2} \mathrm{O}\right)$.

EPR Measurements

The X-band EPR spectrum of $\left[\mathrm{V}_{0.50}\left(\mathrm{H}_{2} \mathrm{O}\right)_{5}\right]_{2}\left[\mathrm{H}_{2}\left(\mathrm{~V}_{10} \mathrm{O}_{28}\right)\right] \cdot 4\left(\mathrm{H}_{2} \mathrm{O}\right)$ is given in Fig. 3. As can be seen in Fig. 3, an eight-line pattern was obtained as a 
result of an unpaired electron being coupled with a vanadium nuclear spin ( $I=$ $7 / 2){ }^{44}$ This spectrum also supports the presence of V(IV) unit in the structure of complex.

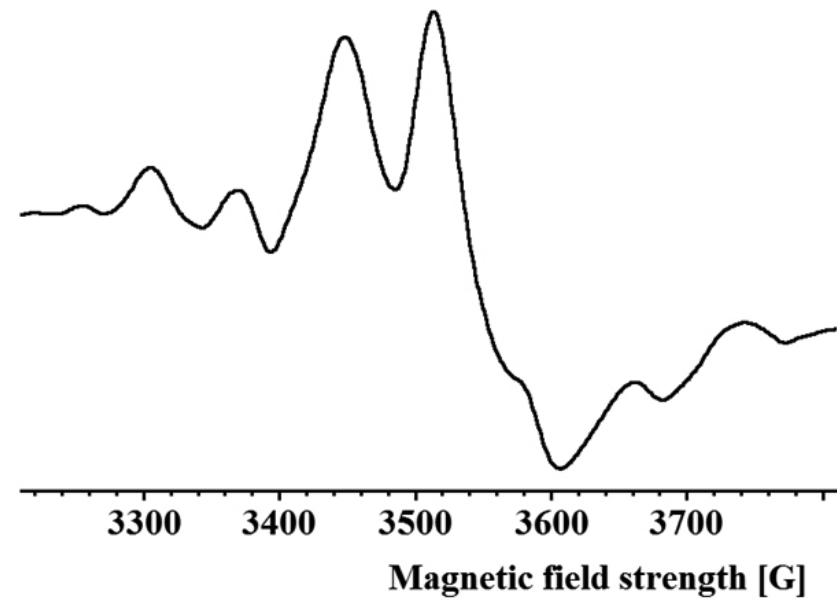

Figure 3. X-band EPR spectrum of $\left[\mathrm{V}_{0.50}\left(\mathrm{H}_{2} \mathrm{O}\right)_{5}\right]_{2}\left[\mathrm{H}_{2}\left(\mathrm{~V}_{10} \mathrm{O}_{28}\right)\right] \cdot 4\left(\mathrm{H}_{2} \mathrm{O}\right)$.

The calculated parameters from the epr spectrum of the complex are given as follows: $\mathrm{g}_{\perp}=1.997, \mathrm{~A}_{\perp}=23 \mathrm{G}, \mathrm{H}_{\perp}=3488 \mathrm{G}, \mathrm{g}_{\|}=1.963, \mathrm{~A}_{\|}=66 \mathrm{G}$ and $\mathrm{H}_{\|}=$ $3549 \mathrm{G}$. From these data, $\mathrm{g}_{\|}<\mathrm{g}_{\perp}$ and $\mathrm{A}_{\|}>\mathrm{A}_{\perp}$ relationships were obtained. This case is characteristic for an axially compressed $\mathrm{d}_{\mathrm{xy}}^{1}$ configuration..$^{51,52}$

Cyclic Voltammetry (CV) Study

The electrochemical redox properties of the compound in $0.1 \mathrm{M} \mathrm{KBr}$ solution have been investigated using $\mathrm{CV}$ technique. The compound gave two cathodic waves at -1.03 and $-1.35 \mathrm{~V}$, respectively (Fig. 4).

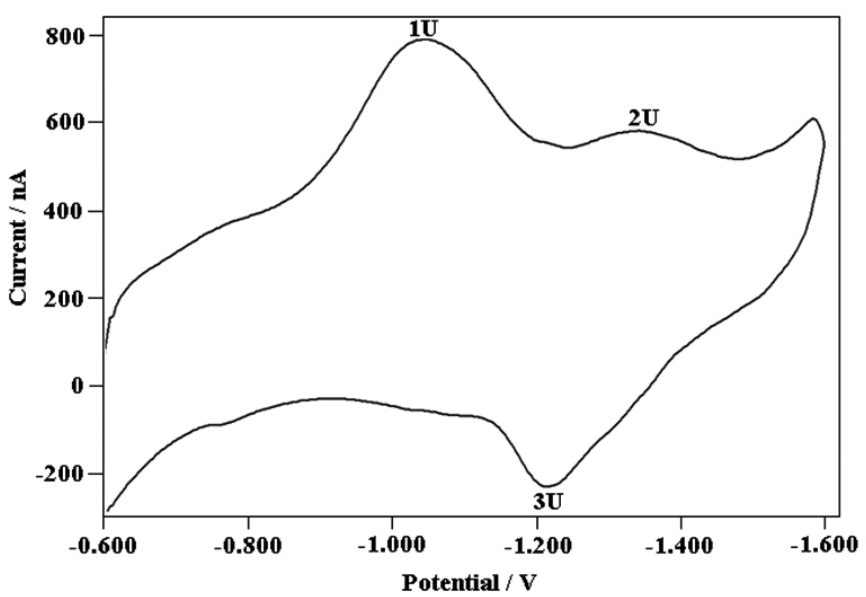

Figure 4. Cyclic voltammogram of $\left[\mathrm{V}_{0.50}\left(\mathrm{H}_{2} \mathrm{O}\right)_{5}\right]_{2}\left[\mathrm{H}_{2}\left(\mathrm{~V}_{10} \mathrm{O}_{28}\right)\right] \cdot 4\left(\mathrm{H}_{2} \mathrm{O}\right)$ in $0.1 \mathrm{M} \mathrm{KBr}$ solution (Experimental conditions: scan rate of $800 \mathrm{mV} / \mathrm{s}$, equilibrium time of $5 \mathrm{~s}$, medium drop size of $0.0154 \mathrm{~cm}^{2}$ and hanging mercury drop electrode as working electrode).

It was reported that $\mathrm{V}(\mathrm{V})$ characteristically gives two cathodic waves in acidic, neutral, and some complex-forming media. The first wave represents the reduction to V(IV), while the second wave has properties identical with those of the cathodic wave of $\mathrm{V}(\mathrm{IV}) \cdot{ }^{53}$ At potentials more negative than about $-0.6 \mathrm{~V}$, the reduction of $\mathrm{V}$ (IV) proceeds directly to $\mathrm{V}$ (II). In the case of $\mathrm{V}$ (II), the reduction to the elemental vanadium is never observed; only anodic waves are obtained. The first step of oxidation gives V(III). ${ }^{53}$

In Fig. 4, the first cathodic wave can be assigned to the reduction of V(V) to V(IV) in agreement with previous reports ${ }^{53}$ while the second wave at more negative potential may be attributed to the reduction of $\mathrm{V}$ (IV) to $\mathrm{V}$ (II). In addition, the anodic wave at $-1.22 \mathrm{~V}$ may be ascribed to the oxidation of $\mathrm{V}(\mathrm{II})$ to $\mathrm{V}(\mathrm{III})$.
Crystal Structure Description of the Compound

The ORTEP diagram of the title compound, a decavanadate salt, $\left[\mathrm{V}_{050}\left(\mathrm{H}_{2}\right.\right.$ $\left.\mathrm{O})_{5}\right]_{2}\left[\mathrm{H}_{2}\left(\mathrm{~V}_{10} \mathrm{O}_{28}\right)\right] \cdot 4\left(\mathrm{H}_{2} \mathrm{O}\right)$ with thermal ellipsoids pictured at a $30 \%$ probability is shown in Fig. 5. The crystallographic data and hydrogen bonding are given in Tables 1 and 3, respectively. The selected bond lengths and angles of the title compound are listed in Table 4. Single crystal X-ray diffractions confirm the molecular structure of the title molecule, $\left[\mathrm{V}_{0.50}\left(\mathrm{H}_{2} \mathrm{O}\right)_{5}\right]_{2}\left[\mathrm{H}_{2}(\mathrm{~V}\right.$ $\left.\left.{ }_{0} \mathrm{O}_{28}\right)\right] \cdot 4\left(\mathrm{H}_{2} \mathrm{O}\right)$, decavanadate salt. The molecular structure of compound is shown in Fig. 6(a). Its structure consists of a diprotonated decavanadate unit, a binuclear V(IV) moiety with two water bridges and four water molecules of crystallization Fig. $6(\mathrm{~b})$. The structures of $\left[\mathrm{H}_{2}\left(\mathrm{~V}_{10} \mathrm{O}_{28}\right)\right]^{4-}$ and $\left[\mathrm{V}_{10} \mathrm{O}_{28}\right]^{6-}$ were already reported in detail..$^{24,54,55}$ In the present study, the bond lengths and angles of $\left[\mathrm{H}_{2}\left(\mathrm{~V}_{10} \mathrm{O}_{28}\right)\right]^{4-}$ anion are similar to data given in the literature. ${ }^{24,54,55}$ The dihydrogen decavanadate anion contains ten edge-sharing $\mathrm{VO}_{6}$ octahedra as reported in the literature. ${ }^{24}$ The crystal structure of the compound is mainly stabilized by electrostatic attraction forces of $\left[\mathrm{H}_{2}\left(\mathrm{~V}_{10} \mathrm{O}_{28}\right)\right]^{4-}$ with the $\mathrm{V}(\mathrm{IV})$ cations, $\left[\left(\mathrm{V}_{0.50}\left(\mathrm{H}_{2} \mathrm{O}\right)_{5}\right)_{2}\right]^{4+}$. At the cationic V(IV) dimer, each of the hydrated V(IV) ions of 0.5 mole is coordinated by five water molecules (Fig. 6). The $\mathrm{V}(\mathrm{IV})-\mathrm{O}$ bond length distances are ranging from 2.337 (3) to 2.378 (3) $\AA$ (Table 4). Besides, there are $\mathrm{O}-\mathrm{H} \cdots \mathrm{O}$ hydrogen bonding interactions (Fig. 6a) which play an important role in the structural stabilization, and the $\mathrm{O} \cdots \mathrm{O}$ distances vary between $2.803-3.037 \AA$ (Table 3 ). The angles which correspond to these interactions are between $142^{\circ}-178^{\circ}$ (Table 3) that fit well with the previous predictions. ${ }^{56,57}$

Table 3. Hydrogen-bond geometries $\left(\AA,^{\circ}\right)$ for $\left[\mathrm{V}_{0.50}\left(\mathrm{H}_{2} \mathrm{O}\right)_{5}\right]_{2}\left[\mathrm{H}_{2}\left(\mathrm{~V}_{10} \mathrm{O}_{28}\right)\right]$ $4\left(\mathrm{H}_{2} \mathrm{O}\right)$

\begin{tabular}{|c|c|c|c|c|}
\hline$D-\mathrm{H} \cdots A$ & $D-\mathrm{H}$ & $\mathrm{H} \cdots A$ & $D \cdots A$ & $D-\mathrm{H} \cdots A$ \\
\hline $\mathrm{O} 15-\mathrm{H} 15 B \cdots \mathrm{O} 5^{\mathrm{i}}$ & $0.81(1)$ & $2.17(2)$ & $2.953(3)$ & $163(4)$ \\
\hline $\mathrm{O} 17-\mathrm{H} 17 B \cdots \mathrm{O} 10^{\mathrm{i}}$ & $0.82(1)$ & $2.04(1)$ & $2.852(3)$ & $170(4)$ \\
\hline $\mathrm{O} 17-\mathrm{H} 17 A \cdots \mathrm{O} 2^{\mathrm{ii}}$ & $0.82(1)$ & $2.23(1)$ & $3.037(3)$ & $168(4)$ \\
\hline $\mathrm{O} 15-\mathrm{H} 15 A \cdots \mathrm{O} 7^{\mathrm{iii}}$ & $0.81(1)$ & $2.13(2)$ & $2.873(3)$ & $152(4)$ \\
\hline $\mathrm{O} 16-\mathrm{H} 16 A \cdots \mathrm{O} 6$ & $0.81(1)$ & $2.04(2)$ & $2.828(3)$ & $165(5)$ \\
\hline $\mathrm{O} 16-\mathrm{H} 16 B \cdots \mathrm{O} 99^{\mathrm{i}}$ & $0.81(1)$ & $2.06(2)$ & $2.864(3)$ & $168(5)$ \\
\hline $\mathrm{O} 20-\mathrm{H} 20 B \cdots \mathrm{O} 2$ & $0.82(1)$ & $2.14(2)$ & $2.941(4)$ & $165(5)$ \\
\hline $\mathrm{O} 18-\mathrm{H} 18 B \cdots \mathrm{O} 11^{\mathrm{iv}}$ & $0.82(1)$ & $1.99(1)$ & $2.804(3)$ & $171(4)$ \\
\hline $\mathrm{O} 19-\mathrm{H} 19 A \cdots \mathrm{O} 12^{\mathrm{iv}}$ & $0.82(1)$ & $1.98(1)$ & $2.803(3)$ & $178(4)$ \\
\hline $\mathrm{O} 21-\mathrm{H} 21 A \cdots \mathrm{O} 9$ & $0.82(1)$ & $2.34(6)$ & $3.031(3)$ & $142(8)$ \\
\hline
\end{tabular}

Symmetry codes: (i) $-\mathrm{x}+2,-\mathrm{y}+1,-\mathrm{z}+1$; (ii) $-\mathrm{x}+2,-\mathrm{y}+1,-\mathrm{z}+2$; (iii) $\mathrm{x}, \mathrm{y}+1$, $\mathrm{z}$; (iv) $-\mathrm{x}+1,-\mathrm{y}+2,-\mathrm{z}+1$.

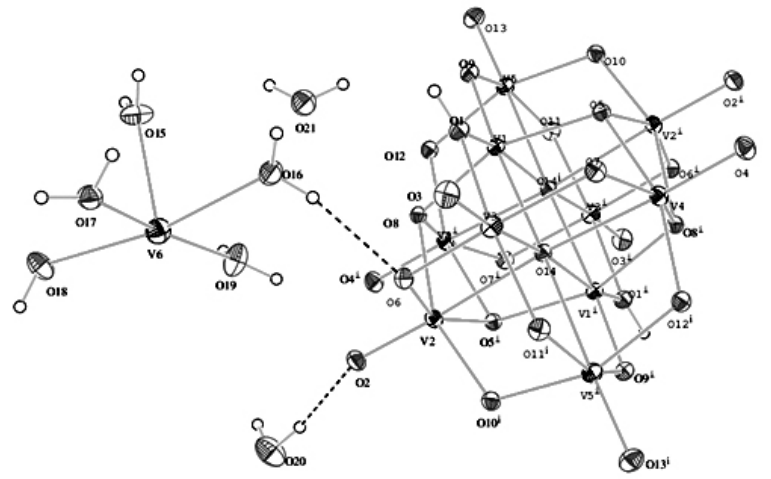

Figure 5. ORTEP plot of the $\left[\mathrm{V}_{0.50}\left(\mathrm{H}_{2} \mathrm{O}\right)_{5}\right]_{2}\left[\mathrm{H}_{2}\left(\mathrm{~V}_{10} \mathrm{O}_{28}\right)\right] \cdot 4\left(\mathrm{H}_{2} \mathrm{O}\right)$ compound showing the atom-numbering scheme and $30 \%$ probability displacement ellipsoids for the non-hydrogen atoms. The hydrogen bonds are shown as dashed lines. 


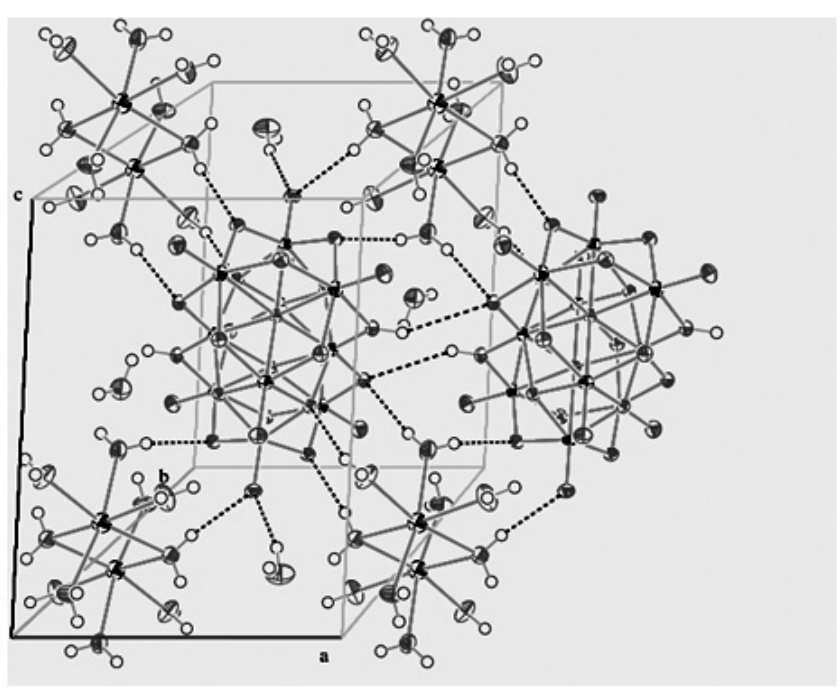

(a)

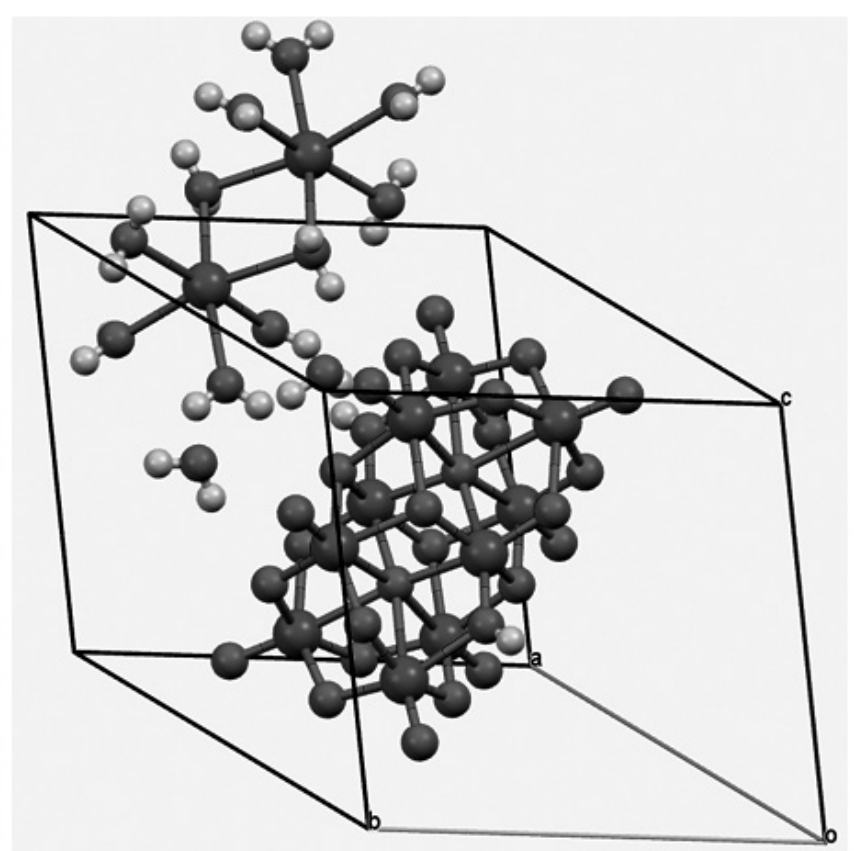

(b)

Figure 6. (a) Crystal-packing diagram of the title compound, $\left[\mathrm{V}_{0.50}\left(\mathrm{H}_{2} \mathrm{O}\right.\right.$ )$\left._{5}\right]_{2}\left[\mathrm{H}_{2}\left(\mathrm{~V}_{10} \mathrm{O}_{28}\right)\right] \cdot 4\left(\mathrm{H}_{2} \mathrm{O}\right)$, along $\mathrm{b}$ axis. Hydrogen bonds are shown as dashed lines. (b) Perspective view of the unit cell of decavanadate salt. Two vanadium atoms, V(IV), formed bridge via two water molecules.

Zhang and $\mathrm{Chen}^{58}$ investigated magnetic exchange interaction in the $\mu$-hydroxo bridged V(IV) dimers. They reported that the distances between the $\mathrm{V}(\mathrm{IV})$ site and the oxygen atom of the bridging aqua ligand (2.332 and 2.500 $\AA$ ) are much longer than the distances between the V(IV) site and the oxygen atom of the bridging hydroxo ligand (1.959 and $1.967 \AA)$. At the bridging V(IV) moiety of the title compound, the distance of V6-O17 is 2.409 (3) $\AA$ (Table 4). This result may support the presence of the bridging aqua ligand instead of the bridging hydroxo ligand.
Table 4. Selected bond lengths $(\AA)$ and angles $\left({ }^{\circ}\right)$ for $\left[\mathrm{V}_{050}\left(\mathrm{H}_{2} \mathrm{O}\right)_{5}\right]_{2}\left[\mathrm{H}_{2}(\mathrm{~V}\right.$ $\left.\left.{ }_{10} \mathrm{O}_{28}\right)\right] \cdot 4\left(\mathrm{H}_{2} \mathrm{O}\right)$

\begin{tabular}{|c|c|c|c|}
\hline $\mathrm{V} 6-\mathrm{O} 18$ & $2.337(3)$ & $\mathrm{V} 6-\mathrm{O} 19$ & $2.378(3)$ \\
\hline $\mathrm{V} 6-\mathrm{O} 15$ & $2.339(3)$ & $\mathrm{V} 6-\mathrm{O} 17$ & $2.409(3)$ \\
\hline $\mathrm{V} 6-\mathrm{O} 16$ & $2.339(3)$ & & \\
\hline O18-V6-O15 & $84.19(11)$ & $\mathrm{O} 16-\mathrm{V} 6-\mathrm{O} 19$ & $88.49(11)$ \\
\hline O18-V6-O16 & $169.87(12)$ & $\mathrm{O} 18-\mathrm{V} 6-\mathrm{O} 17$ & $91.06(10)$ \\
\hline O15-V6-O16 & $88.10(12)$ & $\mathrm{O} 15-\mathrm{V} 6-\mathrm{O} 17$ & $97.11(11)$ \\
\hline $\mathrm{O} 18-\mathrm{V} 6-\mathrm{O} 19$ & $97.51(10)$ & $\mathrm{O} 16-\mathrm{V} 6-\mathrm{O} 17$ & $83.37(11)$ \\
\hline O15-V6-O19 & $86.07(11)$ & $\mathrm{O} 19-\mathrm{V} 6-\mathrm{O} 17$ & $171.14(10)$ \\
\hline $\mathrm{O} 4-\mathrm{V} 4-\mathrm{O} 7-\mathrm{V} 3$ & $-175.16(11)$ & $\mathrm{O} 2-\mathrm{V} 2-\mathrm{O} 6-\mathrm{V} 3$ & $175.05(11)$ \\
\hline $\mathrm{O} 3-\mathrm{V} 3-\mathrm{O} 7-\mathrm{V} 4$ & $177.91(11)$ & $\mathrm{O} 3-\mathrm{V} 3-\mathrm{O} 6-\mathrm{V} 2$ & $-178.33(11)$ \\
\hline
\end{tabular}

When vanadium compounds with high oxidation states are dissolved in water, various hydrolytic, acid/base, condensation and redox reactions can be observed. In addition, it is well known that an inter-conversion between V(IV) and $\mathrm{V}(\mathrm{V})$ oxidation states exists. ${ }^{59,60}$ In some circumstances, vanadate $(+5)$ is readily reduced to $\mathrm{V}(\mathrm{IV})$ or $\mathrm{V}(\mathrm{III})$ with the formation of an oxidized product. The V(IV) oxidation state can be also maintained by the appropriate reducing agents. ${ }^{60}$

Crystal structure determination, especially, the obtaining signals from the epr measurements for the title compound have revealed that a dynamic redox process is involved between $\mathrm{V}(\mathrm{V})$ species $\left(\mathrm{NH}_{4} \mathrm{VO}_{3}\right)$ and chinhydrone during its synthesis, as similar to the overall reaction being represented by the following equation:

$$
2 \mathrm{~V}^{+5}+\mathrm{H}_{2} \mathrm{Q} \rightleftarrows 2 \mathrm{~V}^{+4}+\mathrm{Q}+2 \mathrm{H}^{+}
$$

where $\mathrm{H}_{2} \mathrm{Q}=$ hydroquinone and $\mathrm{Q}=$ para-benzoquinone. ${ }^{61}$ It is also well known that chinhydrone consists of para-benzoquinone with hydroquinone, 1:1 redox couple. ${ }^{62}$ Finally, the synthesized complex includes not only V(V) but also V(IV) units.

\section{NMR Spectroscopy Study}

${ }^{1} \mathrm{H}$ NMR spectrum of the title compound dissolved in $\mathrm{D}_{2} \mathrm{O}$ is shown in Fig. 7. The residual solvent (hydrogen-deuterium-oxygen, HDO) peak appears at $4.65 \mathrm{ppm}$ (Fig. 7). The signals at about $2.01 \mathrm{ppm}$ are attributed to the coordinated $\mathrm{H}_{2} \mathrm{O}$ at $\left[\left(\mathrm{V}_{050}\left(\mathrm{H}_{2} \mathrm{O}\right)_{5}\right)_{2}\right]^{4+}$ cation. ${ }^{63}$ The chemical shift at $5.24 \mathrm{ppm}$ can be assigned to the bridging hydroxyl groups $\mathrm{s}^{64,65}$ at $\left[\mathrm{H}_{2}\left(\mathrm{~V}_{10} \mathrm{O}_{28}\right)\right]^{4-}$ anion. Unfortunately, other signals could not be assigned.

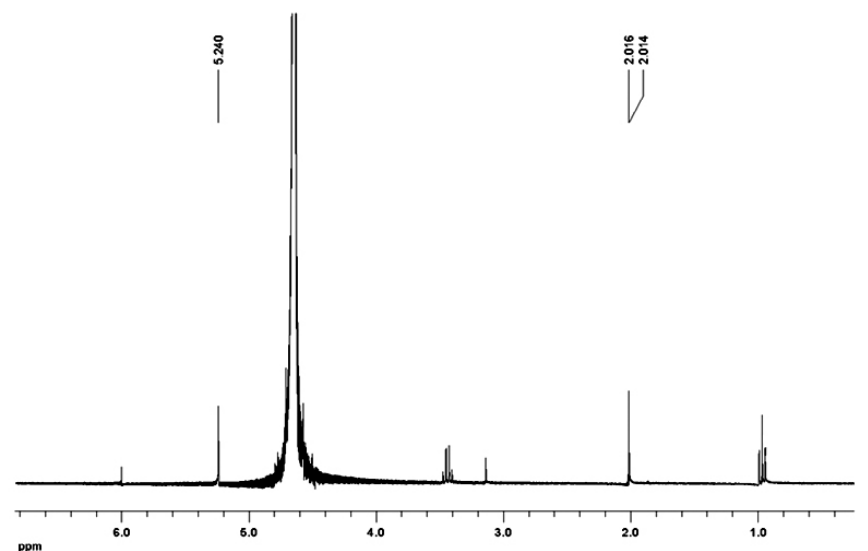

Figure 7. ${ }^{1} \mathrm{H}$ NMR spectrum of $\left[\mathrm{V}_{0.50}\left(\mathrm{H}_{2} \mathrm{O}\right)_{5}\right]_{2}\left[\mathrm{H}_{2}\left(\mathrm{~V}_{10} \mathrm{O}_{28}\right)\right] \cdot 4\left(\mathrm{H}_{2} \mathrm{O}\right)$ dissolved in $\mathrm{D}_{2} \mathrm{O}$

\section{CONCLUSIONS}

In conclusion, the study concentrates on the synthesis and characterization of a novel decavanadate salt, $\left[\mathrm{V}_{050}\left(\mathrm{H}_{2} \mathrm{O}\right)_{5}\right]_{2}\left[\mathrm{H}_{2}\left(\mathrm{~V}_{10} \mathrm{O}_{28}\right)\right] \cdot 4\left(\mathrm{H}_{2} \mathrm{O}\right)$. This salt was 
clearly characterized by means of the single crystal X-ray analysis. It has been found that there are electrostatic forces between diprotonated decavanadate anion, $\left[\mathrm{H}_{2}\left(\mathrm{~V}_{10} \mathrm{O}_{28}\right)\right]^{4-}$, and the aqua bridged $\mathrm{V}(\mathrm{IV})$ cation, along with $\mathrm{O}-\mathrm{H} \cdots \mathrm{O}$ hydrogen bonds in the unit cell.

The presence of V(IV) in the structure has been supported by the EPR study. The electrochemical results have signified that the complex has two irreversible $\mathrm{V}(\mathrm{V}) / \mathrm{V}(\mathrm{IV}), \mathrm{V}(\mathrm{IV}) / \mathrm{V}$ (II) reduction processes and a $\mathrm{V}(\mathrm{II}) / \mathrm{V}$ (III) oxidation process. Furthermore, the bridging $\mathrm{V}-\mathrm{O}-\mathrm{V}$ groups and decameric vanadate units were also characterized by FT-IR and UV-Vis. spectroscopy techniques. In addition, the presence of the coordinated water molecules and hydroxo groups supported by NMR analysis.

As a result, the structure of the decavanadate salt synthesized in this study is different from its other salts ${ }^{24-27}$ according to the arrangement of cations and transition metal species. An exciting part of this study is that the mentioned synthesis method may play an important role in the synthesis of different decavanadate compounds in the future.

Supplementary Materials. - CCDC 1472918 contains the supplementary crystallographic data for this paper. These data can be obtained free of charge via http://www.ccdc.cam.ac.uk/conts/retrieving.html, (or from the Cambridge Crystallographic Data Centre, 12, Union Road, Cambridge CB2 1EZ, UK; fax: +44 1223 336033).

\section{REFERENCES}

1. Y. Shechter, A. Shisheva, Endeavour, 17, 27, (1993).

2. D. Rehder, Coord. Chem. Rev., 182, 297, (1999).

3. A. Butler, J.V. Walker, Chem. Rev., 93, 1937, (1993)

4. D. Rehder, Angew. Chem. Int. Ed. Engl., 30, 148, (1994).

5. L.C.W. Baker, D.C. Glick, Chem. Rev., 98, 3, (1998).

6. M. Weyand, H.J. Hecht, M. Kiez, M.F. Liaud, H. Vilter, D. Schomburg, J. Mol. Biol., 595, 293, (1999).

7. A. Messerschdt, L. Prade, R. Wever, Biol. Chem., 378, 309, (1997).

8. D. del Rio, A. Galindo, J. Tejedo, F.J. Bedoya, A. Ienco, C. Mealli, Inorg. Chem. Commun., 3, 32, (2000)

9. H. Sigel, A. Sigel (Eds.), Metal Ions in Biological Systems, vol. 31, Marcel Dekker, New York, 1995

10. A. Butler, M.J. Clague, G. E. Meister, Chem. Rev., 94, 625, (1994).

11. D.C. Crans, Comment. Inorg. Chem., 16, 35, (1994).

12. A. Butler, C.J. Carrano, Coordin. Chem. Rev., 109, 61, (1991).

13. N.D. Chasteen (Ed.), Vanadium in Biological Systems, Kluwer Academic Publishers, Dordrecht, 1990.

14. S. Ramanadham, J.J. Mongold, R.W. Browsey, G.H. Cros, J.H. McNeill, Am. J. Physiol., 257, H904, (1989).

15. V.G. Yuen, C. Orvig, J.H. McNeill, Can. J. Physiol. Pharmacol., 73, 55, (1995).

16. M. Halberstam, N. Cohen, P. Shlimovich, L. Rossetti, H. Shamoon, Diabetes, 45, 659, (1996).

17. V. Badmaev, S. Prakash, M. Majeed, J. Altern. Complement. Med., 5, 273, (1999).

18. M. Aureliano, D.C. Crans, J. Inorg. Biochem., 103, 536, (2009).

19. M.S. Whittingham, J. Electrochem. Soc., 123, 315, (1978).

20. A. Vejiux, P. Courtini, J. Solid State Chem., 63, 179, (1996).

21. Y. Ueda, Chem. Mater., 10, 2653, (1998).

22. H. Yoshihito, Coordin. Chem. Rev., 255, 2270, (2011).

23. D. M. Tiago, V. Laizé, M. L. Cancela, M. Aureliano, Cell Biology and Toxicology, 24, 253, (2008).

24. H.T. Evans, Inorg. Chem., 5, 967, (1966).

25. I. Mestiri, I. Nagazi, A. Haddad, Journal of the Tunisian Chemical Society, 17, 128, (2015)

26. U. Lee, Y.-H. Jung, H.-C Joo, Acta Cryst. E, 59, i72, (2003).

27. T. Higami, M. Hashimoto, S. Okeya, Acta Cryst. C, 58, i144, (2002).

28. G. Maciejewska, M. Nosek, T. Głowiak, J. Starosta, M. Cieslak-Golonka, Polyhedron, 22, 1415, (2003).

29. D. Omanović, M. Branica, Croat. Chem. Acta, 71, 421, (1998).

30. STOE \& Cie, X-AREA (Version 1.18) and X-RED32 (Version 1.04), STOE \& Cie, Darmstadt, Germany, 2002.

31. G.M. Sheldrick, Acta Crystallogr. A, 64, 112, (2008).

32. L.J. Farrugia, J. Appl. Crystallogr., 30, 565, (1997).

33. A.L. Spek, Acta Crystallogr. D, 65, 148, (2009).

34. L.J. Farrugia, J. Appl. Crystallogr., 32, 837, (1999)

35. V.D. Kassabova-Zhetcheva, L.P. Pavlova, Turk. J. Chem., 35, 215, (2011).

36. M. Shahid, P.K. Sharma, Anjuli, S. Chibber, Z.A. Siddiqi, J. Clust. Sci., 25,
$1435,(2014)$.

37. Z.A. Siddiqi, Anjuli, P.K. Sharma, M. Shahid, M. Khalid, A. Siddique, S Kumar, J. Mol. Struct., 1029, 86, (2012).

38. Y.T. Chua, P.C. Stair, I.E. Wachs, J. Phys. Chem. B, 105, 8600, (2001).

39. S.B. Etcheverry, P.A.M. Williams, D.A. Barrio, V.C. Sálice, E.G. Ferrer, A.M. Cortizo, J. Inorg. Biochem., 80, 169, (2000).

40. O.M. Yaghi, H. Li, T.L. Groy, J. Am. Chem. Soc., 118, 9096, (1996).

41. R.L. Frost, S.J. Palmer, D.A. Henry, R. Pogson, J. Raman Spectrosc., 42, 1447, (2011).

42. R.L. Frost, M.J. Dickfos, J. Raman Spectrosc., 38, 1516, (2007).

43. J.A. Gomes, D.L. Cocke, M.A. Mahmud, H. Moreno, E. Peterson, M.Y. Mollah, J.R. Parga, ECS Transactions, 6, 29, (2008).

44. R.C. Maurya, D. Sutradhar, M.H. Martin, S. Roy, J. Chourasia, A.K. Sharma, P. Vishwakarma, Arabian Journal of Chemistry, 8, 78, (2015).

45. G. Arrambide, D.A. Barrio, S.B. Etcheverry, D. Gambino, E.J. Baran, Biol. Trace Elem. Res., 136, 241, (2010).

46. A. Müller, E. Diemann, C.K. Jørgensen, Struct. Bond, 14, 23, (1973).

47. M. Tarnai, Oxidation of transition metal complexes with 3,7-diazabicyclo[3.3.1]nonane-derived ligands, $\mathrm{PhD}$ Thesis, RuprechtKarls-Universität Heidelberg, Ungarn, 2006.

48. L. Pajdowski, Chem. Zvesti, 19, 192, (1965).

49. S.M. Lewis, D.D. Thomas, Biochemistry, 25, 4615, (1986).

50. S. Ramos, R.O. Duarte, J.J.G. Mourac, M. Aureliano, Dalton T., 7985, (2009).

51. S. Bhattacharya, T. Ghosh, Indian J. Chem. A, 38, 601, (1999).

52. N.A. Mangalam, M.R.P. Kurup, Spectrochim. Acta A, 71, 2040, (2009).

53. Y. Israel, L. Meites, in Encyclopedia of Electrochemistry of the Elements, A.J. Bard (Ed.), Vol. VII, Ch. 2, Marcel Dekker, New York, 1976; pp. $293-$ 466.

54. G. Nowogrocki, E. Baudrin, S. Denis, M. Touboul, Eur. J. Solid State Inorg. Chem., 34, 1011, (1997).

55. E. Rakovský, L. Zúrková, J. Marek, Cryst. Res. Technol., 36, 339, (2001).

56. N. Pavlovic, J. Prevost, A. Spasojevic-de Bire, Cryst. Growth Des., 11, 3778, (2011).

57. A. Najafi, J.T. Mague, M. Mirzaei, J. Iran. Chem. Soc., 13, 773, (2016).

58. L. Zhang, Z. Chen, Chemical Physics Letters, 345, 353, (2001).

59. D.C. Crans, A.S. Tracey, ACS Symposium Series, 711, 2, (1998).

60. C. Pretorius, A solution and solid state study of vanadium complexes, Magister Scientiae Thesis, University of the Free State, Bloemfontein, 2012.

61. J. Burgess (Ed.), Inorganic Reaction Mechanisms, Vol. 1, Part 1, Ch. 5, The Chemical Society, Burlington House, London, 1971; p. 56.

62. http://www.chemicalbook.com/ChemicalProductProperty_DE_ CB9292163.htm (Accessed 18 February 2016)

63. Z.A. Siddiqi, P.K. Sharma, M. Shadid, M. Khalid, S. Kumar, J. Mol Struct., 994, 295, (2011).

64. A. F. A. Peacock, M. Melchart, R. J. Deeth, A. Habtemariam, S. Parsons, P. J. Sadler, Chem. Eur. J., 13, 2601, (2007).

65. http://www.iza-online.org/synthesis/VS 2ndEd/NMR.htm (Accessed 05 November 2016). 